\title{
Detection and differentiation of infectious bursal disease virus from the outbreaks in two layer farms by PCR-RFLP in J os, Nigeria
}

\author{
P. D. Luka ${ }^{1}$, B. Yakubu ${ }^{1}$, A. R. Jambol ${ }^{1}$, B. J. Audu $^{1}$, B. B. Dogonyaro ${ }^{2}$ and O. A. Owolodun ${ }^{1}$ \\ 1. Applied Biotechnology Division, National Veterinary Research Institute, Vom, Plateau State, Nigeria; \\ 2. Viral Research Division, National Veterinary Research Institute, Vom, Plateau State, Nigeria \\ Corresponding author: P. D. Luka, email: pamluka08@gmail.com \\ Received: 25-10-2013, Revised: 05-12-2013, Accepted: 10-12-2013, Published online: 24-01-2014
}

doi: 10.14202/vetworld.2014.30-33 How to cite this article: Luka PD, Yakubu B, Jambol AR, Audu BJ, Dogonyaro BB and Owolodun OA (2014) Detection and differentiation of infectious bursal disease virus from the outbreaks in two layer farms by PCR-RFLP in J os, Nigeria, Veterinary World 7(1): 30-33.

\begin{abstract}
Aim: Characterization of Infectious bursal disease viruses (IBDV) from the two outbreaks in Jos Nigeria, using reverse transcriptase polymerase chain reaction/restriction fragment length polymorphism (RT-PCR/RFLP) technique.

Materials and Methods: A total of 40 bursa samples were collected from two outbreaks in November 2011 from two farms of 6-8 weeks old pullets within Jos South Local Government Area, with mortality between $60-74.2 \%$ in commercially reared layer chicken flocks experiencing signs typical of infectious bursal disease (IBD). All the samples were found to contain IBDV genome by One Step RT-PCR using VP2 gene specific primers.

Result: The assay amplified a 743bp fragment from 701-1444 nucleotides. RT-PCR product was further subjected to restriction digestion using TaqI, MvaI and SacI Restriction enzymes to differentiate classical from very virulent phenotypes. The RFLP profile was found similar for all eight isolates with TaqI and MvaI enzyme but different for SacI. All eight TaqI positive Viruses were further found positive for $M v a I$ digestion and yielded RFLP profile similar to vvIBDV in Europe whereas one isolate was SacI positive and had a RFLP profile similar to classic IBDV strains.
\end{abstract}

Conclusion: The clinical history of high mortality and TaqI and MvaI restriction enzyme positivity revealed that vvIBDV strains still exist in Jos, North central Nigeria.

Keywords: infectious bursal disease virus, Nigeria, outbreak, RT-PCR/RFLP, very virulent

\section{Introduction}

Infectious bursal disease (IBD) or Gumboro is an acute and highly contagious disease of immature chickens. Chickens of age 3 to 6 weeks are most susceptible to clinical infection. The causative agent is Infectious bursal disease virus (IBDV) with primary affinity for actively mitotic B-lymphocytes within the bursa of fabricius where it multiplies. In the process of infection other organs systems are involved in its immunology. Viral activity leads to immune-suppression $[1,2]$ thereby making chickens susceptible to other diseases and subsequently drops in egg production and quality [3].

Infectious bursal disease virus belongs to the genus Avibirnavirus and family Birnaviridae divided into two serotypes ( 1 and 2). Serotype 1 is further subdivided into six (6) subtypes that ranges from apathogenic to very virulent strains for chickens while serotype 2 have been reported to be non-pathogenic $[4,5]$.

The non-enveloped and bi-segmented IBDV dsRNA genome encodes for four structural proteins including: VP1, VP2, VP3, and VP4 and the nonstructural protein VP5. The structural and non-structural proteins VP2-VP4-VP3 and VP5 are encoded by the larger (A) segment of the viral genome as a poly-

Copyright: The authors. This article is an open access article licensed under the terms of the Creative Commons Attribution License (http://creativecommons.org/licenses/by/2.0) which permits unrestricted use, distribution and reproduction in any medium, provided the work is properly cited. protein. The polyprotein is bio-transformed into VP2 and VP3 and viral protease VP4. The VP5 plays a role in maturation and release of the virion while VP1 encodes for RNA dependent RNA polymerase (RdRp) by $\mathrm{B}$ segment of the genome $[2,6]$.

The VP2 house the region responsible for differences in phenotypic characteristics. It is also a major structural protein of the viral capsid that carries highly conformational epitopes responsible for induction of protective antibodies $[7,8]$.

Clinically, IBDV detection and isolation on chick embryo fibroblast is a time consuming and laborious procedure. Serologic and molecular diagnosis enables more exact differentiation of strains. The application of molecular techniques covers detection and characterization with regard to virulence factors and epidemiology of the virus [9]. In other to control this economically important disease of commercial poultry, rapid identification of IBDV strains is vital.

Reverse transcriptase-polymerase chain reaction/ Restriction enzyme analysis (RT-PCR/REA) has been described as a sensitive technique for diagnosis and molecular differentiation of IBDV within the VP2 gene $[10,11]$. Although IBDV is endemic in Nigeria, the present report describes the prevalent strains of IBDV in two commercial layers in Jos, Nigeria using Onestep RT-PCR/REA of the amplified VP2 gene with MvaI, TaqI and SacI restriction enzymes. 


\section{Materials and Methods}

Case history: The samples were collected from carcasses submitted to the Central Diagnostics Laboratory (CDL) of the National Veterinary Research Institute (NVRI), Vom between November and December, 2011. They were from two different layer flocks of 6 and 8 weeks of age, respectively. The farms were located in two different settlements (Bukuru and Vom) south of the city of Jos, Plateau State Nigeria which is approximately 25 and $36 \mathrm{~km}$ from Jos city respectively. Flocks originated from different breeder flocks and kept differently. They all had a history of vaccination for IBD at seven days (1 week) and twenty one days (3 weeks) with live attenuated IBD vaccine. The clinical signs began at 6 and 8 weeks of age for the two farms respectively; the peak mortality occurred between the second and third day of first reported mortalities reaching $20.4 \%$ and $18 \%$ in each flock (Bukuru and Vom), respectively. Mortality was very high (60 - 74.2 $\%$ ) in the two farms and a total of 40 (20 each) bursa samples were collected from the postmortem carcasses for molecular analysis. Ornibur ${ }^{\circledR} \mathrm{V}$ strain (Czech Republic) and IBDV Vom commercial vaccines were used as controls

Viral RNA isolation: One gram of bursae from each sample was weighed and homogenized using a homogenizer or a pestle and mortar with sterile glass. After homogenizing $9 \mathrm{ml}$ of PBS was added and centrifuged in a refrigerated centrifuge at 10,000 rpm for $5 \mathrm{~min}$ to make $10 \%$ tissue suspension. The supernatant was decanted into a sterile tube and kept at $4^{\circ} \mathrm{C}$ for RNA extraction [9] and the pellet discarded into a disinfectant (Virkon $®)$. The viral RNA extraction was carried out using QIAamp Viral RNA Mini kit following the manufacturer's guidelines. Extracted RNA was kept briefly at $4^{\circ} \mathrm{C}$ pending RT-PCR

RT-PCR/ REA: Six $\mu$ l extracted viral RNA was amplified in a single tube in a one step RT-PCR using Titan one Tube RT-PCR system (Roche, Germany) using gene specific primers in a total reaction volume of 50 $\mu 1$. The reaction was carried out in $200 \mu$ l tubes with the following conditions: Each reaction contains $6 \mu \mathrm{l}$ of RNA, 0.2 mM each dNTPs, 10 units of RNase inhibitor (MBI Fermentas), two units of Enzyme mix, MgSO4 and the 5x RT-buffer provided by the manufacturer, $20 \mathrm{mM}$ of the primer $\mathrm{J} 1$ (F) 5'- GGC CCA GAG TCT ACA CCA TAA C - 3') and J2 (R) 5' - CCG GAT TAT GTC TTT GAA GCC - 3', (11), DEPC Nuclease free waster was added to a total volume of $50 \mu \mathrm{l}$. PCR amplification was carried out as follows: Incubation at $42^{\circ} \mathrm{C}$ for $30 \mathrm{~min}$ followed by Initial denaturation at $94^{\circ} \mathrm{C}$ for $2 \mathrm{~min}$ followed by 35 cycles of denaturation at $94^{\circ} \mathrm{C}$ for $30 \mathrm{sec}$, annealing at $50^{\circ} \mathrm{C}$ for $1 \mathrm{~min}$, extension at $72^{\circ} \mathrm{C}$ for $2 \mathrm{~min}$ and a final extension of $72^{\circ} \mathrm{C}$ for 7 min. In all the RT-PCR reaction sets negative and positive controls were included.

The PCR amplicons were resolved on $1.5 \%$ agarose in Tris-borate- EDTA (TBE) buffer gels stained with ethidium bromide. Ten $\mu$ l of the PCR product from each of the tubes were mixed with $6 \mathrm{X}$ buffer and electrophoresed along with 100 bp DNA molecular weight marker (GeneRular, MBI Fermentas) at a constant $100 \mathrm{~V}$ for $60 \mathrm{~min}$ in $1 \times$ TBE buffer. Amplified product was viewed under UV light for the expected 743 bp product and documented by a UV transilluminator.

Restriction enzyme analysis: The amplified product ( 4 from each farm, $n=8$ ) was digested using the enzyme: MvaI, TaqI and SacI according to manufacturer's instructions (Roche®, Germany). A total of $25 \mu \mathrm{l}$ of reaction volume was prepared and incubated at $37^{\circ} \mathrm{C}$ for $1 \mathrm{hr}$. Digested fragments were electrophoretically separated on $1.5 \%$ agarose for $60 \mathrm{~min}$. The sizes of the restriction fragment length polymorphism (RFLP) bands were determined by comparison with a $100 \mathrm{bp}$ DNA ladder (Fermentas, USA).

\section{Results}

The variable region of the VP2 gene of the suspected samples was amplified by One - step RTPCR (Figure-1). The 743 bp products of representative samples were analyzed in other to differentiate the different strains. The products were digested with three restriction enzymes (MvaI, TaqI and SacI) and the RFLP compared (Table-1).

Three bands of 425, 321, and 101 bp were obtained on electrophoresis gel following digestion of DNA fragments with TaqI which revealed the presence of two restriction sites (Table-1). Four bands were also obtained following digestion of PCR products with MvaI. Agarose gel electrophoresis bands of 424, 209, 172 and 119 bp were obtained indicating three restriction sites. Moreover, agarose gel electrophoresis bands of 475 and 285 were observed after SacI digestion of sample 4 (BF 36) and vaccine control DNA segments from the representative samples suggesting also one restriction site.

\section{Discussion}

IBDV is a very serious economic disease of poultry that has persisted in Nigeria for decades. One of the first outbreaks was reported from the Western part of Nigeria in 1973. Since then the disease has continued to occur [12]. Due to the endemic nature of the disease in Nigeria, vaccination has been the major tool in prevention and control of the disease. Besides, immunization failures have been suggested during challenge by vvIBDV $[13,14]$.

Outbreaks of IBD are detected clinically and confirmed either serologically or via molecular techniques. Molecular techniques in Nigeria have not gain popularity in the use of restriction enzyme analysis as a tool to determine field circulating strains. The IBDV primers (J1/J2) developed by Jackwood and Sommer, [14] amplified a 743 bp fragment from 701-1444 nucleotides of the VP2 hyper-variable region.

In the present study, IBDV was differentiated by 
Table-1. RFPL patterns of representative outbreak genomes of 743 bp products generated from RT/PCR

\begin{tabular}{|c|c|c|c|c|c|c|c|c|c|c|c|}
\hline \multirow[t]{2}{*}{ Sr. No } & \multirow[t]{2}{*}{ Sample ID } & \multicolumn{3}{|c|}{ Taql } & \multicolumn{4}{|c|}{ Mval } & \multicolumn{3}{|c|}{ Sacl } \\
\hline & & 452 & 321 & 101 & 424 & 209 & 172 & 119 & 475 & 285 & 137 \\
\hline 1. & BF4 & $\sqrt{1}$ & $\checkmark$ & $\checkmark$ & $\sqrt{1}$ & & 1 & 1 & & & \\
\hline 2. & BF31 & $\checkmark$ & $\checkmark$ & $\checkmark$ & $\checkmark$ & & $\checkmark$ & $\checkmark$ & & & \\
\hline 3. & BF19 & $\checkmark$ & $\checkmark$ & $\checkmark$ & $\checkmark$ & & $\checkmark$ & 1 & & & \\
\hline 4. & BF36 & $\sqrt{1}$ & $\checkmark$ & & & $\checkmark$ & $\checkmark$ & 1 & $\checkmark$ & $\checkmark$ & $\checkmark$ \\
\hline 5. & BF6 & 1 & $\checkmark$ & & & $\checkmark$ & $\checkmark$ & $\checkmark$ & & & \\
\hline 6. & BF7 & $\checkmark$ & $\checkmark$ & & & $\checkmark$ & $\checkmark$ & $\checkmark$ & & & \\
\hline 7. & $\mathrm{~V} 1$ & $\checkmark$ & $\checkmark$ & & & $\checkmark$ & $\checkmark$ & 1 & & & \\
\hline 8. & V2 & $\sqrt{1}$ & $\checkmark$ & & & $\checkmark$ & $\checkmark$ & $\sqrt{ }$ & & & \\
\hline 9. & Control & $\checkmark$ & $\checkmark$ & & & $\checkmark$ & $\checkmark$ & 1 & $\checkmark$ & $\checkmark$ & $\checkmark$ \\
\hline
\end{tabular}

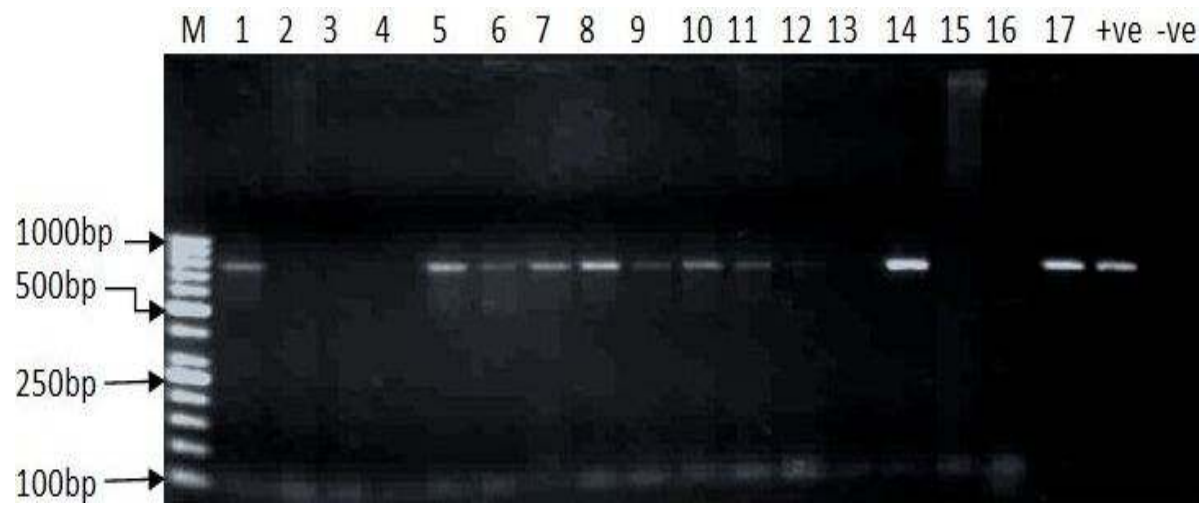

Figure-1. A 1.5\% Agarose gel electrophoresis of RT-PCR products using Vp2 specific primers. Lane M: 100 bp DNA marker (Fermentas). Lane 1: 1-17 are suspected IBD samples. Lane +ve and -ve are positive and negative controls respectively.

One-step RT-PCR/RFLP analysis of 8 clinical samples detected and submitted to TaqI, MvaI and SacI restriction analysis, which confirmed IBDV in the two farms with a mortality of $60-74.2 \%$ recorded. Previous survey by Ezeibe et al., [15] reported a mortality of 0 $75 \%$ in Nigeria following an experimental challenge study with a Nigerian very virulent isolate.

Similar patterns were observed for TaqI and $\mathrm{MvaI}$ for both field and vaccine samples. Fragments obtained by TaqI indicated the presence of the restriction site which is found in vvIBDV strains globally like the UK661 strain reported in Europe [16] and Indian MH1/97 and Croatian strains reported by Kataria et al., [17] and Bidin et al., [18]. Fragment 101 was not found in some of the strains suggesting a mutation of the restriction site $[17,19]$.

Digesting the RT-PCR products with MvaI (Isoschizomer of $B s t N I$ ) gave a similar RFLP profile to vvIBDV reported in Europe, US, Banglandesh and Pakistan $[10,11,14]$. This is similar to the report of Owoade et al., [20] who reported vvIBDV from the sequences of all 40 samples generated the Southwestern States of Nigeria from 1995-2000. Similarly, Adamu et al., [21] also reported vvIBDV from the North western States, Nigeria.

Several researchers have reported the ability of ScaI to differentiate between classical IBDV from vvIBDV strains. From our study, the vaccine and sample BF36 showed similar pattern.

This is in agreement with other reports that SacI restriction site is present in cvIBDV strains [22]. The SacI restriction site is introduced into the genome of cvIBDV strains by silent mutations at nucleotide position 867 [23]. Our results shows SacI restriction site exit is one of the field sample, the presence of point mutations cannot be ruled out and this mutations can play a role in influencing the pathogenicity of the virus [21]. Arguably, the loss of the SacI restriction site offers a rapid method for the RFLP analysis and therefore proving that RT-PCR/RFLP is a simple and sensitive method for detection of genetic variations among isolates that are closely related serologically, which could not be differentiated using current serologic methods.

Our findings suggest that vvIBDV is prevalent on the Jos Plateau and also circulates in other parts of Nigeria [20,21]. Arguably, the differences in mortality rate may also be related to the challenge studies, sample size and the presence of other exacerbating diseases as coccidiosis [24, 25] which can occur concurrently. Nonetheless the IBD mortality rates we found were similar $(75 \%)$ to that reported recently in an experimental study with a vvIBDV in Nsukka [15].

Although IBV has been a problem in Nigeria for a long time, studies did not go as far as characterizing the circulating virus in the field using RFLP. Our study carried out restriction fragment length polymorphism (RFLP) of the VP2 gene fragment of some of the viruses involved in two recent outbreaks in 2012 shows. Restriction pattern shows the involvement of vvIBD circulating viruses suggesting that these viruses involved in outbreaks are not the classical but very virulent strains of the virus. In addition, the present study also suggest that the VP2 region maybe be undergoing rapid genetic changes and thus supporting the earlier observation of Adamu et al., [21] who 
reported that the IBD vaccine virus is more prone to mutations thereby rendering it virulent. Between outbreaks, the IBD viruses RFLP pattern were very similar suggesting possible similarities among the circulating viruses.

\section{Conclusion}

Reverse transcriptase polymerase chain reaction/ RFLP is a sensitive and rapid method for differentiating circulating IBDV strains in and within flocks. This study confirmed the presence of vvIBDV implicated in the two outbreaks in Jos, north central Nigeria. This may be associated with the high mortalities reported during the outbreaks.

\section{Authors' contributions}

PDL, BY and OAO designed the study. LPD: Drafted the manuscript. ARJ, BJA and BBD carried out laboratory work, analyzed and interpreted the results. All authors read and approved the final manuscript.

\section{Acknowledgements}

The authors are grateful to the Executive Director, National Veterinary Research Institute, Vom for funding the work and the Management of the department of Applied Molecular Biology for allowing this work to be carried out.

\section{Competing interests}

The authors declare that they have no competing interests.

\section{References}

1. Long, F.Y., Guo, Y. M., Wang, Z., Liu, D., Zhang, B.K., and Yang, X. (2011) Conjugated linoleic acids alleviate infectious bursal disease virus-induced immunosuppression in broiler chickens. Poultry Science. $90: 1926-1933$.

2. Delmas, B., Mundt, E.,Vakharia, V.N., and Wu, J.L. (2011) Family birnaviridae. In: King, A.M.Q., Lefkowitz, E., Adams, M.J., Carstens, E.B. (Eds) Virus Toxonomy Ninth Report of the International Committee on Taxonomy of Viruses. Academic press Inc., San Diego, California.507.

3. Arnold, M., Durairaj, V., Mundt, E., Schulze, K., Breunig, K.D., and Behrens, S.E. (2012) Protective Vaccination against Infectious Bursal Disease Virus with Whole Recombinant Kluyveromyces lactis Yeast Expressing the Viral VP2 Subunit. PLoS ONE, 7(9): e428 70.

4. Wang, Y., Wu, X., Li, H., Wu, Y., Shi, L., Zheng, X., Luo, M., Yan, Y., and Zhou, J. (2009) Antibody to VP4 protein is an indicator discriminating pathogenic and nonpathogenic IBDV infection. Mol. Immunol.46 (10):1964-9.

5. Abdel-Alem, G.A., Awaad, M.H.H., and Saif, Y.M. (2003) Characterization of Egyptian field strains of infectious bursal disease virus. Avian Dis. 47: 1452-1457.

6. Van Den Berg, T.P (2000) Acute infectious bursal disease in poultry: Areview. Avian Pathology, 29 (3): 175-194.

7. Jackwood, J.D., Sommer-Wagner, S.E., Stoute, S.T., Woolcock, P.R., Crossley, B.M., Hietala, S.K., and Charlton, B.R. (2009) Characteristics of a Very Virulent Infectious Bursal Disease Virus from California. Avian Diseases, 53(4): 592-600.

8. Escaffre, O., Nouen, C.L., Amelot, M., Ambroggio, X., Ogden, M.K., Guionie, O., Toquin, D., Muller, H., Islam, M., and Eterradossi, N. (2013) Both genome segments contribute to the pathogenicity of very virulent infectious bursal disease virus. J. Virol. 87(5): 2767-2780.

9. Office International for Epizootics (OIE): Infectious bursal disease In Manual of Standards for Diagnostic Tests and Vaccines for Terrestrial Animals. 5 edition. Paris, OIE; http:// www.oie.int/fileadmin/Home/eng/Health_standards/tahm/ 2.07.11_IBD.pdf. Accessed on 10 July 2013.

10. Islam, M.R., Rahman, S., Noor, M., Chowdhury, E.H., and Müller, H. (2012) Differentiation of infectious bursal disease virus (IBDV) genome segment B of very virulent and classical lineage by RT-PCR amplification and restriction enzyme analysis. Arch Virol. 157(2):333-6.

11. Zahoor, A.M., Abubakar, M., Naim, S., Khan, Q.M., and Arshed, M.J. (2011) Molecular Typing of Field Isolates from two outbreaks of Infectious Bursal Disease Virus from Pakistan. Vet World, 4(7): 297-300.

12. Ojo, M.O., Oduye, O.O., Noibi, L.M., and Idowu, A.L. (1973) Gumboro-like disease in Nigeria. Trop. Anim Hlth and Prod. 5: 52-56.

13. Hassan, M.K. (2004) Very virulent infectious bursal disease virus in Egypt: Epidemiology, isolation and immunogenicity of classic vaccine. Vet. Res. Comm, 28: 347-356.

14. Jackwood, D.J., and Sommer, S.E. (1999) Restriction fragment polymorphisms in the VP2 gene of infectious bursal disease viruses from outside the United States. Avian Diseases, 43: 310-314.

15. Ezeibe, M.C.O., Okoye, J.O.A., Ogunniran, T.M., Animoke, P.C.J., Nwankwo, I.A., and Ngene, A.A. (2013) Mortality rates from a Nigerian isolate of the Infectious Bursa Disease Virus and passive haemagglutination antibody titer that protects chicks against challenge with the virus isolate. Health, 5: 1355-1359.

16. Brown, M.D., Green, P., and Skinner, M.A. (1994) VP2 sequences of "very virulent" isolates of infectious bursal disease virus are closely related to each other but are distinct from those of "classical" strains. J. Gen. Virol. 75: 675-680.

17. Kataria, R.S., Tiwari, A.K., Butchaiah, G., and Kataria, J.M. (1999) Differentiation of infectious bursal disease virus strains by restriction analysis of RT-PCR-amplified VP2 gene sequences. Acta Virol. 43: 245-249.

18. Bidin, Z., Lojkic, I., Grce, M., Cajavec, S., and Pokric, B. (2001) Differentiation of infectious bursal disease virus strains at a genomic level. Veterinarski Arhiv 71 (6): 325-336.

19. Ikuta, N., El-Attrache, J., Villegas, P., Garcia, E.M., Lunge, V.R., Fonseca, A.S.K., Oliveira C. and Marques, E.K. (2001) Molecular characterization of Brazilian infectious bursal disease viruses. Avian Dis. 45: 297-306.

20. Owoade, A.A., Mulders, M.N., Kohnen, J., Ammerlaan, W., and Muller, C.P. (2004) High sequence diversity in infectious bursal disease virus serotype 1 in poultry and turkey suggest West African origin of very virulent strains. Arch. Virol, 149 (4): 653-72.

21. Adamu, J., Owoade, A.A., Abdu, P.A., Kazeem, H.M., and Fatihu, M.Y. (2013) Characterization of field and vaccine infectious bursal disease viruses from Nigeria revealing possible virulence and regional markers in the VP2 minor hydrophilic peaks. Avian Path, 42 (5): 420-33

22. Sellers, H.S., Villegas, P.N., Seal, B.S., and Jackwood, D.J. (1999) Antigenic and molecular characterization of three infectious bursal disease virus field isolates. Avian Dis. 43: 198-206.

23. Zierenberg, K., Raue, R., and Muller, H. (2001) Rapid identification of "very virulent" strains of Infectious bursal disease virus by reverse transcription-polymerase chain reaction combined with restriction enzyme analysis. Avian Path. 30: 55-62.

24. Kabell, S., Handberg, K.J., and Bisgaard, M. (2006) Impact of coccidial infection on vaccine- and vvIBDV in lymphoid tissues of SPF chickens as detected by RT-PCR. Acta Vet. Scand. 48:17.

25. Naqi, S., Thompson, G., Bauman, B., and Mohammed, H. (2001) The exacerbating effect of infectious bronchitis virus infection on the Infectious bursal disease virus induced suppression of opsonization of Escherichia coli antibody in chicken. Avian Dis, 45 (1):52-60.

$* * * * * * * *$ 